\title{
The Analysis of Local Revenues, Intergovernmental Grants (Revenue Sharing, Block Grants and Specific Grants) and Foreign Investment on the Economic Growth of Coal-Producing Regions in South Sumatera 2002-2015
}

\section{Analisis Pengaruh Pendapatan Asli Daerah (PAD), Dana Perimbangan (DBH, DAU dan DAK) dan Penanaman Modal Asing (PMA) Terhadap Pertumbuhan Ekonomi Pada Daerah Penghasil Batubara di Provinsi Sumatera Selatan Tahun 2002-2015}

\author{
Muhammad Ikbal Aziz'1); Bernadette Robiani²); Azwardi 2) \\ 1) Politeknik Akamigas Palembang \\ 2) Universitas Sriwijaya

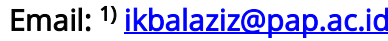

How to Cite :

Aziz, M. I., Robiani, B., Azwardi. (2021). The Analysis of Local Revenues, Intergovernmental Grants (Revenue Sharing, Block Grants and Specific Grants) and Foreign Investment on the Economic Growth of CoalProducing Regions in South Sumatera 2002-2015. Jurnal Ekonomi Manajemen Akuntansi dan Keuangan, 2(4). DOI: https://doi.org/10.53697/emak.v2i4

ARTICLE HISTORY

Received [30 September 2021]

Revised [05 October 2021]

Accepted [15 October 2021]

KEYWORDS

Local Revenues,

Intergovernmental Grants,

Foreign Investment, Economic

Growth

This is an open access article under the $C C-B Y$-SA license

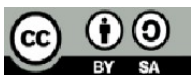

\section{ABSTRAK}

Penelitian ini bertujuan untuk menganalisis pengaruh Pendapatan Asli Daerah (PAD), Dana Perimbangan (DBH, DAU dan DAK) dan Penanaman Modal Asing (PMA) terhadap Pertumbuhan Ekonomi pada daerah penghasil batubara di Provinsi Sumatera Selatan, yakni pada Kabupaten Muara Enim, Kabupaten Musi Banyuasin, Kabupaten Lahat, Kabupaten Musi Rawas dan Kabupaten Ogan Komering Ulu. Data dalam penelitian ini menggunakan data sekunder, berupa data panel dari tahun 2002 sampai dengan tahun 2015 yang diperoleh dari publikasi BPS, DJPK, dinas atau instansi terkait lainnya. Metode analisa data menggunakan metode kuantitatif dengan uji asumsi klasik, regresi linear berganda dan uji statistik menggunakan aplikasi Eviews 8. Hasil penelitian menunjukkan bahwa secara simultan Pendapatan Asli Daerah (PAD), Dana Perimbangan (DBH, DAU dan DAK) dan Penanaman Modal Asing (PMA) mempunyai pengaruh yang signifikan terhadap pertumbuhan ekonomi. Sedangkan secara parsial, Pendapatan Asli Daerah (PAD) dan Penanaman Modal Asing (PMA) berpengaruh positif namun tidak signifikan terhadap pertumbuhan ekonomi pada 5 (lima) kabupaten penghasil batubara. Selain itu, didapatkan hasil bahwa hasil produksi batubara, royalty dan land rent yang diterima belum mampu mengatasi jumlah penduduk miskin di daerah penghasil batubara tersebut.

\section{ABSTRACT}

This study focuses on the analysis of local revenues, Intergovernmental Grants (Revenue Sharing, Block Grants and Specific Grants) and foreign investment on the economic growth of coal-producing regencies in South Sumatera, namely, Muara Enim, Musi Banyuasin, Lahat, Musi Rawas and Ogan Komering Ulu. Secondary data are used in this study in form of panel data from the period of 2002 to 2015. The data are obtained from Central 
Bureau of Statistics, Directorate-General of Regional Fiscal Balance and other related institutions. Quantitative method using classic assumption, multiple regression analysis and statistical tests through Eviews 8 are used in this study. The result shows that, simultaneously, local revenues, Intergovernmental Grants (Revenue Sharing, Block Grants and Specific Grants) and foreign investment have positive impact on the economic growth. Moreover, partially, local revenues and foreign investment have positive and insignificant effect on the 5 coal-producing regions. It is also shown that coal production, royalty and land rent has not been able to overcome the number of poor people in the coal-producing regions..

\section{PENDAHULUAN}

Pelaksanaan otonomi daerah yang sebelumnya mengacu pada UU No. 32 Tahun 2004 Tentang Pemerintah Daerah dan UU No. 33 Tahun 2004 Tentang Perimbangan Keuangan Antara Pemerintah Pusat dan Pemerintah Daerah telah digantikan oleh UU No. 23 Tahun 2014 tentang Pemerintahan Daerah, dimana urusan-urusan pemerintahan antara pemerintah pusat dan pemerintah daerah menjadi semakin jelas. Apabila dana perimbangan yang menjadi sumber keuangan daerah seperti tercantum dalam UU No. 33 Tahun 2004 dikaitkan dengan urusan-urusan pemerintahan dalam UU No. 23 Tahun 2014, maka dapat diketahui bahwa urusan-urusan pemerintahan daerah yang didanai oleh salah satu jenis dana perimbangan yaitu dana alokasi umum ialah diantaranya urusan pemerintahan konkuren, baik itu urusan wajib maupun pilihan seperti urusan di bidang pendidikan, kesehatan, tenaga kerja, pertanahan dan urusan-urusan lainnya yang diserahkan ke daerah, dimana urusan-urusan tersebut menjadi dasar pelaksanaan otonomi daerah.

Pelaksanaan otonomi daerah ini diberlakukan diseluruh wilayah Negara Kesatuan Republik Indonesia baik itu pada tingkat provinsi maupun ditingkat kabupaten dan/atau kota. Penyelenggaraan urusan pemerintahan di daerah dilaksanakan berdasarkan asas Desentralisasi, Dekonsentrasi dan Tugas Pembantuan. Pemerintah Pusat menetapkan kebijakan sebagai dasar dalam menyelenggarakan Urusan Pemerintahan. Secara umum, sumber dana bagi daerah terdiri dari Pendapatan Asli Daerah, Dana Perimbangan (Dana Bagi Hasil, Dana Alokasi Umum dan Dana Alokasi Khusus) dan pinjaman daerah, dekonsentrasi dan tugas pembantuan. Tiga sumber pertama langsung dikelola oleh Pemerintah Daerah melalui APBD, sedangkan yang lainnya dikelola oleh Pemerintah Pusat melalui kerjasama dengan Pemerintah Daerah.

Pemerintah daerah dalam rangka menjalankan proses pemerintahan di daerah wajib menyusun Anggaran Pendapatan dan Belanja Daerah (APBD). APBD adalah rencana keuangan tahunan Pemerintahan Daerah yang dibahas dan disetujui bersama oleh Pemerintah Daerah dan Dewan Perwakilan Rakyat Daerah. Menurut Todaro (2000), pembangunan merupakan suatu proses multidimensional yang melibatkan perubahan-perubahan besar dalam struktur sosial, sikap mental yang sudah terbiasa dan lembaga-lembaga nasional termasuk pula percepatan/akselerasi pertumbuhan ekonomi, pengurangan ketimpangan dan pemberantasan kemiskinan yang absolut.

Arsyad (2010), menyatakan bahwa pembangunan ekonomi merupakan suatu upaya untuk meningkatkan pendapatan riil perkapita dalam jangka panjang dan diikuti oleh perbaikan sistem kelembagaan. Tujuan utama dari pembangunan adalah menciptakan kesejahteraan masyarakat dan kesejahteraan masyarakat dapat dilihat dari meningkatnya pertumbuhan ekonomi dan meratanya distribusi pendapatan.

Menurut Todaro (2000), meskipun laju pertumbuhan ekonomi tidak secara otomatis dapat memberi jawaban atas berbagai macam persoalan kesejahteraan, namun hal tersebut tetap merupakan unsur penting setiap program pembangunan realistis yang sengaja dirancang untuk mengentaskan kemiskinan. Jika dilihat dari hasil penelitian dan data statistik, akan terlihat bahwa meskipun pertumbuhan ekonomi telah berjalan dengan pesat namun pertumbuhan yang pesat ini 
telah membawa akibat yang menghawatirkan, yaitu terjadinya ketimpangan distribusi pendapatan yang lebih buruk.

Kuncoro (2006) juga mengemukakan bahwa pertumbuhan ekonomi yang cepat belum tentu dapat terjadi keberhasilan dalam pembangunan. Justru pertumbuhan ekonomi yang cepat akan berdampak terhadap ketimpangan dan distribusi pendapatan, karena sejatinya pertumbuhan ekonomi tidak selalu diikuti dengan pemerataan. Ada semacam trade off antara pertumbuhan ekonomi yang tinggi dengan pemerataan pendapatan dalam suatu pembangunan ekonomi. Ketika pembangunan ekonomi lebih ditujukan untuk pemerataan pendapatan maka pertumbuhan ekonomi akan membutuhkan waktu yang relatif lama untuk mencapai tingkat pertumbuhan yang tinggi. Begitu pula, sebaliknya jika pembangunan lebih difokuskan untuk mencapai tingkat pertumbuhan yang tinggi maka akan semakin besar kemungkinan terjadinya ketimpangan dalam distribusi pendapatan.

Menurut Todaro dan Smith (2006), pembangunan ekonomi merupakan suatu proses multidimensional yang mencakup berbagai perubahan mendasar atas struktur sosial, sikap-sikap masyarakat, dan institusi-institusi nasional, di samping tetap mengejar akselerasi pertumbuhan ekonomi, penanganan ketimpangan pendapatan, serta pengentasan kemiskinan. Pembangunan ekonomi tersebut mencakup berbagai aspek-aspek pembentuk seperti ekonomi, sosial, politik dan lainnya dimana aspek-aspek tersebut saling bersinergi untuk mencapai keberhasilan pembangunan baik di tingkat pusat maupun daerah. Oleh karena itu, diperlukan peran serta baik dari masyarakat maupun pemerintah dalam mencapai tujuan tersebut.

Menurut Saragih (2003), Pendapatan Asli Daerah (PAD) yang merupakan salah satu sumber penerimaan daerah, memiliki keterkaitan dengan pertumbuhan ekonomi, dimana PAD dapat dikatakan sebagai modal yang digunakan dalam pembiayaan pembangunan daerah. Daerah yang pertumbuhan ekonominya positif mempunyai kemungkinan kenaikan PAD atau dengan kata lain adanya peningkatan PAD merupakan akses dari pertumbuhan ekonomi atau Produk Domestik Regional Bruto (PDRB) dan diyakini antara PAD dan pertumbuhan ekonomi terdapat adanya korelasi.

Menurut Waluyo (2008) investasi juga memegang peranan penting dalam teori pembangunan, sehingga sering disebut sebagai engine of growth. Investasi yang bersifat penanaman modal langsung akan berdampak pada penyerapan tenaga kerja, sehingga pada akhirnya dapat meningkatkan output nasional. Investasi tersebut berasal dari sektor pemerintah maupun sektor swasta. Investasi pemerintah dilakukan dan dibiayai melalui APBN/APBD, sedangkan investasi swasta dilakukan melalui Penanaman Modal Dalam Negeri (PMDN) dan Penanaman Modal Asing (PMA).

Berdasarkan Undang-Undang Republik Indonesia Nomor 25 Tahun 2007 dalam Pasal 1 Ayat 9 Tentang Penanaman Modal, penanaman modal asing adalah kegiatan menanam modal untuk melakukan usaha di wilayah negara Republik Indonesia yang dilakukan oleh penanam modal asing, baik yang menggunakan modal asing sepenuhnya maupun yang berpatungan dengan penanam modal dalam negeri. Modal asing membantu dalam industrialisasi, membangun modal overhead ekonomi, dan menciptakan kesempatan kerja. Modal asing tidak hanya membawa uang dan mesin tetapi juga keterampilan teknik. Penanaman modal asing (PMA) membuka daerah-daerah terpencil dan menggarap sumber-sumber yang belum dimanfaatkan. Provinsi Sumatera Selatan dikenal juga sebagai provinsi di Indonesia yang memiliki kekayaan alam yang potensial, salah satunya adalah pertambangan batubara. Produksi batubara itu sendiri berasal dari beberapa kabupaten di Provinsi Sumatera Selatan, salah satunya adalah yang tersebar pada 5 (lima) kabupaten, yakni Kabupaten Ogan Komering Ulu (OKU), Muara Enim, Lahat, Musi Rawas dan Musi Banyuasin. 


\section{LANDASAN TEORI}

Teori Pertumbuhan Ekonomi

Beberapa ahli ekonomi mengutarakan berbagai macam pendapat dan teorinya mengenai pertumbuhan ekonomi, khususnya pertumbuhan ekonomi pada suatu daerah. Menurut Arsyad (2000), menyatakan bahwa pertumbuhan ekonomi daerah diartikan sebagai kenaikan Produk Domestik Regional Bruto (PDRB) tanpa memandang apakah kenaikan itu lebih besar atau lebih kecil dari tingkat pertumbuhan penduduk atau apakah perubahan struktur ekonomi terjadi atau tidak. Hal ini berarti bahwa pertumbuhan ekonomi daerah secara langsung ataupun tidak langsung akan menciptakan lapangan kerja.

\section{Teori Pertumbuhan Ekonomi Klasik}

Menurut pandangan ahli-ahli ekonomi Klasik ada 4 (empat) faktor yang mempengaruhi pertumbuhan ekonomi, yaitu: jumlah penduduk, jumlah stok barang-barang modal, luas tanah dan kekayaan alam, serta teknologi yang digunakan. Walaupun menyadari bahwa pertumbuhan ekonomi tergantung pada banyak faktor, ahli-ahli ekonomi Klasik terutama menitikberatkan perhatiannya kepada pengaruh pertambahan penduduk kepada pertumbuhan ekonomi (Sukirno, 2010).

Penduduk yang terus bertambah akan menyebabkan pada suatu jumlah penduduk yang tertentu produksi marjinal telah sama dengan pendapatan per kapita. Pada keadaan ini pendapatan per kapita mencapai nilai yang maksimum. Jumlah penduduk pada waktu itu dinamakan penduduk optimum. Secara grafik teori penduduk optimum dapat ditunjukkan seperti dalam gambar 2.1. Kurva Ypk menunjukkan tingkat pendapatan per kapita pada berbagai jumlah penduduk, dan $\mathrm{M}$ adalah puncak kurva tersebut. Maka penduduk optimal adalah jumlah penduduk sebanyak No, dan pendapatan per kapita yang paling maksimum adalah YO.

\section{Teori Pertumbuhan Ekonomi Neo-Klasik}

Model pertumbuhan ekonomi Neo-Klasik Solow merupakan pilar yang sangat memberi kontribusi terhadap teori pertumbuhan Neo-Klasik sehingga penggagasnya, Robert Solow, dianugrahi hadiah Nobel bidang ekonomi. Pada intinya, model ini merupakan pengembangan dari formulasi Harrod-Domar dengan menambah faktor kedua, yakni tenaga kerja serta memperkenalkan variabel independen ketiga, yakni teknologi, kedalam persamaan pertumbuhan. Namun, berbeda dari model Harrod-Domar yang mengasumsikan skala hasil tetap dengan koefisien baku, model pertumbuhan Neo-Klasik Solow berpegang skala hasil yang terus berkurang (diminishing return) dari input tenaga kerja dan modal jika keduanya dianalisis secara terpisah; jika keduanya dianalisis secara bersamaan atau sekaligus, Solow juga memakai asumsi skala hasil tetap tersebut (Todaro dan Smith, 2004).

\section{Pendapatan Daerah}

Pendapatan daerah merupakan penerimaan yang sangat penting bagi pemerintah daerah dalam menunjang pembangunan daerah guna membiayai proyek-proyek dan kegiatan-kegiatan daerah. Menurut Abdul Halim (2002 : 64), dalam bukunya Akuntansi Sektor Publik Akuntansi Keuangan Daerah menyatakan bahwa Pendapatan Daerah adalah semua penerimaan daerah dalam bentuk peningkatan aktiva atau penurunan utang dalam berbagai sumber dalam periode tahun anggaran bersangkutan.

Berdasarkan pengertian tersebut dapat diambil kesimpulan bahwa pendapatan daerah merupakan penerimaan yang diperoleh pemerintah daerah yang dapat ditinjau dari tingkat kenaikan aktiva ataupun penurunan utang yang dapat digunakan oleh pemerintah dalam membangun dan mengembangkan suatu daerah dalam periode tahun anggaran yang bersangkutan. 


\section{Dana Perimbangan}

Widjaja (2002) menyampaikan bahwa Dana Perimbangan merupakan sumber pendapatan daerah yang berasal dari APBN untuk mendukung pelaksanaan kewenangan pemerintah daerah dalam mencapai tujuan pemberian otonomi kepada daerah, yaitu terutama peningkatan pelayanan dan kesejahteraan masyarakat yang semakin baik.

\section{Kerangka Pemikiran}

Untuk menggambarkan hubungan antara variabel independen dan variabel dependen yang digunakan dalam penelitian ini, berikut digambarkan kerangka pikiran penelitiannya :

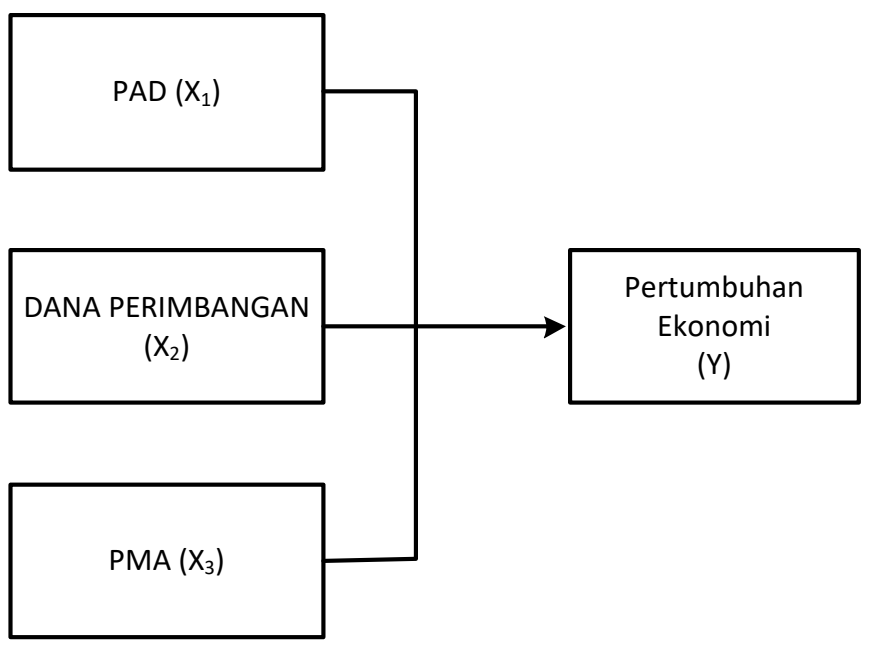

Gambar 1. Skema Hubungan Antara PAD, Dana Perimbangan dan PMA Terhadap Pertumbuhan
Ekonomi METODE PENELITIAN

\section{Metode Analisis}

Metode analisis yang digunakan dalam penelitian ini adalah analisis regresi berganda dengan data panel menggunakan data cross section dengan 5 daerah penghasil batubara di Provinsi Sumatera Selatan dan data time series periode tahun 2002-2015. Pengolahan data menggunakan alat bantuan software Eviews 8.

\section{Analisis Regresi}

Teknik regresi dipilih dalam dalam penelitian ini karena merupakan gabungan antar kedua jenis data yaitu data cross section dan data time series, yaitu data terdiri dari 5 daerah penghasil batubara dalam kurun waktu 14 (empat belas) tahun.

Penelitian ini menggunakan beberapa metode analisis dalam menjawab tujuan yang akan dicapai. Alat analisis tersebut meliputi :

1. Dalam pemilihan metode apa yang akan digunakan dalam analisis data panel dapat dilakukan dua uji yaitu :

a. Uji F (uji chow)

Uji ini digunakan menentukan pemilihan metode PLS atau FE. Uji membandingkan nilai Fhitung dengan Ftabel dengan menggunakan hipotesis:

$H_{0}=$ Metode Pooled Least Square (PLS)

$H_{1}=$ Metode Fixed Effect (FE)

Apabila nilai $\mathrm{F}$ hitung $>\mathrm{F}$ tabel maka $H_{0}$ ditolak dan begitu sebaliknya. 
a. Uji Hausman

Uji ini digunakan untuk mentukan pemilihan antara metode FE atau RE dengan menggunakan hipotesis :

$H_{0}=$ Metode Random Effect (RE)

$H_{1}=$ Metode Fixed Effect (FE)

2. Data panel adalah gabungan antara data runtut waktu (time series) dan data silang (cross section). Data runtut waktu biasanya meliputi satu objek/individu tetapi meliputi beberapa periode. Sehingga model yang dapat dibentuk adalah :

$$
Y_{i t}=\beta_{0}+\beta_{1} X_{1 i t}+\beta_{2} X_{2 i t}+\beta_{3} X_{3 i t}+\varepsilon_{i}
$$

Keterangan :

$\mathrm{Y}=$ Pertumbuhan Ekonomi

$\beta_{0}=$ Intersep

$\mathrm{X}_{1}=$ Pendapatan Asli Daerah (PAD)

$X_{2}=$ Dana Perimbangan (DP)

$X_{3}=$ Penanaman Modal Asing (PMA)

$\beta_{1}=$ Koefisien regresi variabel Pendapatan Asli Daerah (PAD)

$\beta_{2}=$ Koefisien regresi variabel Dana Perimbangan (DP)

$\beta_{5}=$ Koefisien regresi variabel Penanaman Modal Asing (PMA)

$\varepsilon=$ Variabel gangguan atau kesalahan (disturbance/error terms)

$\mathrm{i}=$ Unit cross section 5 daerah penghasil batubara

$\mathrm{t}=$ Unit time series tahun 2002-2015

\section{Koefisien Determinasi $R^{2}$ (Goodness of Fit)}

Koefisien Determinasi $\left(R^{2}\right)$ adalah salah satu bentuk nilai statistik yang dapat digunakan untuk mengetahui apakah ada hubungan pengaruh antara dua variabel

Menurut Gujarati (2003) Koefisien determinasi $\left(R^{2}\right)$ merupakan ukuran ringkas yang menginformasikan kepada kita seberapa baik sebuah garis regresi sampel sesuai dengan datanya. Koefisien determinasi pada intinya mengukur seberapa jauh kemampuan model dalam menerangkan variasi variabel dependen. Nilai koefisien determinasi adalah antara nol dan satu. Rumus untuk $\mathrm{R}^{2}$ adalah sebagai berikut :

$$
R^{2}=\frac{\left(\bar{Y}_{1}-\bar{Y}\right)^{2}}{\left(Y_{1}-\bar{Y}\right)^{2}}
$$

Gujarati juga menambahkan bahwa terdapat dua sifat $\mathrm{R}^{2}$,yaitu:

1. Besarannya tidak pernah negatif

2. Batasannya adalah $0 \leq R^{2} \leq 1$. Jika $R^{2}$ bernilai 1 , artinya kesesuaian garisnya tepat. Akan tetapi, jika $\mathrm{R}^{2}$ bernilai nol maka tidak ada hubungan antara regresan dengan regresor.

\section{HASIL DAN PEMBAHASAN}

\section{Hasil dan Pembahasan}

\section{Koefisien Determinasi $R^{2}$ (Goodness of Fit)}

Nilai koefisien determinasi $\left(R^{2}\right)$ menggambarkan kemampuan model regresi untuk menjelaskan variabel dependennya (pertumbuhan ekonomi), sedangkan nilai diluar koefisien determinasi $(1-R)^{2}$ dijelaskan oleh faktor-faktor diluar model. Dari hasil estimasi, besarnya $\mathrm{R}^{2}$ yang diperoleh adalah 0.839858. Artinya variabel $Y$ (Pertumbuhan Ekonomi) dalam model sebesar $83,99 \%$ dipengaruhi oleh variabel-variabel bebas yang ada di dalam model yaitu $X_{1}(P A D), X_{2}$ (Dana 
Perimbangan) dan $X_{3}$ (PMA), sementara sisanya sebesar $16,01 \%$ dipengaruhi oleh variabel atau faktor lain yang tidak terdapat dalam model.

\section{Uji Signifikansi Simultan (Uji Statistik F)}

Uji signifikansi parameter atau uji $\mathrm{F}$ dilakukan dengan tujuan untuk melihat pengaruh variabel-variabel independen secara bersama-sama atau keseluruhan. Parameternya adalah bila nilai Fhitung lebih besar dibandingkan nilai Ftabel atau nilai probabilitas Fstatistik lebih kecil dari nilai $\alpha 5 \%$ maka dapat dikatakan bahwa secara keseluruhan variabel-variabel independen dalam model berpengaruh signifikan terhadap variabel dependennya.

Nilai Fhitung sebesar 46.45076, sedangkan nilai Ftabel yang dilihat dari Tabel $\mathrm{F} \alpha 5 \%$ untuk $\mathrm{n}$ $=70$ dan $\mathrm{k}=3$ ( $\mathrm{df}$ pembilang $=\mathrm{k}-1$, $\mathrm{df}$ penyebut $=\mathrm{n}-\mathrm{k}$ ) adalah sebesar 2,74. Oleh karena Fhitung lebih besar dari Ftabel, maka $\mathrm{H}_{0}$ ditolak sehingga secara bersama-sama semua variabel bebas pada penelitian ini secara serentak berpengaruh terhadap variabel pertumbuhan ekonomi.

\section{Uji Signifikansi Parsial (Uji Statistik t)}

Uji signifikansi parsial bertujuan untuk melihat signifikansi pengaruh variabel independen secara parsial terhadap variabel dependen. Parameter yang digunakan adalah suatu variabel independen dikatakan secara signifikan berpengaruh terhadap variabel dependen bila nilai t hitung lebih besar dari nilai t tabel atau juga dapat diketahui dari nilai probabilitas t statistik yang lebih kecil dari nilai $\alpha=5 \%$ nilai t tabel dilihat dari $n=70$ dan $k=3$ yakni sebesar (dari tabel 1.) :

Tabel 1. Uji Signifikansi Parsial

\begin{tabular}{|c|c|c|c|}
\hline Variable & t-Statistic & Prob. & Keterangan \\
\hline LNX1? & 1.643837 & 0.1053 & $\begin{array}{l}\text { Tidak Terdapat Pengaruh Signifikan pada } \alpha= \\
0,05\end{array}$ \\
\hline LNX2? & 3.432093 & 0.0011 & $\begin{array}{l}\text { Terdapat Pengaruh Signifikan pada } \alpha=0,05 \\
\text { Tidak Terdapat Pengaruh Signifikan pada } \alpha=\end{array}$ \\
\hline LNX3? & 0.850813 & 0.3981 & 0,05 \\
\hline
\end{tabular}

Sumber : Hasil penelitian (data diolah), 2017

Interpretasi Hasil Analisis

Dari model regresi terlihat bahwa sesuai dengan penelitian terdahulu variabel $X_{1}(P A D), X_{2}$ (Dana Perimbangan) dan $\mathrm{X}_{3}$ (PMA) secara simultan mempunyai pengaruh yang signifikan terhadap pertumbuhan ekonomi. Hal tersebut dapat dibuktikan dengan nilai koefisien determininasi $\left(R^{2}\right)$ yang mencapai adalah 0.839858 atau sebesar $83,99 \%$ yang menginterpretasikan bahwa variasi pertumbuhan ekonomi dipengaruhi oleh variabel independen, yakni variabel $X_{1}, X_{2}$ dan $X_{3}$, sedangkan sisanya sebesar $16,01 \%$ dipengaruhi oleh variabel atau faktor lain yang tidak terdapat dalam model (diluar model).

\section{Pembahasan}

Berikut disajikan pembahasan analisa pengaruh Pertumbuhan Ekonomi pada kabupaten penghasil batubara dan hasil regresi pengaruh variabel PAD, Dana Perimbangan (DBH, DAK dan DAU) dan PMA terhadap Pertumbuhan Ekonomi kabupaten penghasil batubara di Provinsi Sumatera Selatan. 
Rata-rata Pertumbuhan Ekonomi antar Kabupaten Penghasil Batubara

Tabel 2. Jumlah Rata-rata PDRB Kabupaten Penghasil Batubara di Provinsi Sumatera Selatan Tahun 2002 s.d. 2015

\begin{tabular}{|l|l|l|}
\hline No. & Kabupaten & Rata-Rata PDRB (Rp.) \\
\hline 1. & Musi Banyuasin & 16.726 .770 .785 .714 \\
\hline 2. & Muara Enim & 14.916 .753 .642 .857 \\
\hline 3. & Musi Rawas & 6.068 .405 .000 .000 \\
\hline 4. & Lahat & 5.135 .959 .142 .857 \\
\hline 5. & Ogan Komering Ulu & 4.610 .828 .928 .571 \\
\hline
\end{tabular}

Sumber: Hasil penelitian (data diolah), 2017

Pada tabel 2 di atas, rata-rata jumlah PDRB tertinggi terdapat pada Kabupaten Musi Banyuasin dan yang paling rendah adalah Kabupaten Ogan Komering Ulu. Jika diperbandingkan data jumlah rata-rata PDRB dengan data tabel jumlah produksi batubara (Tabel 4.1), royalty dan land rent (Tabel 4.2) serta jumlah penduduk miskin (Tabel 4.3), dapat dilihat bahwa :

1. Berdasarkan data produksi batubara tahun 2006 s.d. 2014, Kabupaten Muara Enim sebagai penghasil batubara terbanyak hanya memiliki jumlah rata-rata PDRB berada pada urutan nomor 2 setelah Kabupaten Musi Banyuasin. Sedangkan kabupaten OKU sebagai penghasil batubara terendah juga berada paling rendah untuk jumlah rata-rata PDRB.

2. Berdasarkan data jumlah royalty dan land rent tahun 2014, Kabupaten Muara Enim sebagai penerima royalty dan land rent terbanyak hanya memiliki jumlah rata-rata PDRB berada pada urutan nomor 2 setelah Kabupaten Musi Banyuasin. Sedangkan Kabupaten Musi Rawas sebagai penerima royalty dan land rent terendah juga berada pada urutan nomor 3 untuk jumlah rata-rata PDRB.

3. Berdasarkan data jumlah penduduk miskin tahun 2013, Kabupaten Muara Enim sebagai kabupaten yang memiliki penduduk miskin terbanyak hanya memiliki jumlah rata-rata PDRB berada pada urutan nomor 2 setelah Kabupaten Musi Banyuasin. Sedangkan kabupaten OKU sebagai kabupaten yang memiliki penduduk miskin terendah hanya memiliki jumlah rata-rata PDRB berada pada urutan paling akhir.

Berdasarkan uraian di atas, dapat dilihat bahwa Kabupaten Muara Enim sebagai kabupaten yang memiliki jumlah rata-rata PDRB cukup tinggi (urutan nomor 2 setelah Kabupaten Musi Banyuasin) dan memiliki jumlah produksi batubara terbanyak serta memperoleh royalty dan land rent terbanyak, justru memiliki penduduk miskin terbesar kedua setelah Kabupaten Musi Banyuasin.

Berbeda jauh dengan Kabupaten Musi Banyuasin yang memiliki jumlah rata-rata PDRB paling tinggi di antara 4 (empat) kabupaten lainnya, justru memiliki penduduk miskin paling banyak, meskipun jumlah produksi batubaranya menempati urutan nomor 2 setelah Kabupaten Muara Enim, termasuk royalty dan land rent yang diterima menempati urutan nomor 3 setelah Kabupaten Muara Enim dan Kabupaten Lahat

\section{Pengaruh Pendapatan Asli Daerah Terhadap Pertumbuhan Ekonomi}

Hasil pengujian pengaruh PAD $\left(\mathrm{X}_{1}\right)$ terhadap pertumbuhan ekonomi $(\mathrm{Y})$ diperoleh nilai koefisien regresi sebesar 1.643837 dengan nilai signifikansi 0.1053 (di atas 0,05), artinya tidak terdapat pengaruh signifikan, dimana PAD secara individual tidak mempengaruhi Pertumbuhan Ekonomi.

Akan tetapi, jika dilihat dari perhitungan sebelumnya, yakni nilai koefisien dari masingmasing kabupaten penghasil batubara tersebut. Diperoleh bahwa setiap $1 \%$ kenaikan PAD pada masing-masing kabupaten akan meningkatkan 0,20\% Pertumbuhan Ekonomi pada masing-masing kabupaten tersebut. 
Pengaruh Dana Perimbangan Terhadap Pertumbuhan Ekonomi

Hasil pengujian pengaruh Dana Perimbangan $\left(\mathrm{X}_{2}\right)$ terhadap pertumbuhan ekonomi $(\mathrm{Y})$ diperoleh nilai koefisien regresi sebesar 3.432093 dengan nilai signifikansi 0.0011 (di bawah 0,05), artinya terdapat pengaruh signifikan, dimana Dana Perimbangan secara individual mempengaruhi Pertumbuhan Ekonomi.

Dan jika dilihat dari perhitungan sebelumnya, yakni nilai koefisien dari masing-masing kabupaten penghasil batubara tersebut. Diperoleh bahwa setiap 1\% kenaikan Dana Perimbangan pada masing-masing kabupaten akan meningkatkan 0,78\% Pertumbuhan Ekonomi pada masingmasing kabupaten tersebut.

Pengaruh Penanaman Modal Asing Terhadap Pertumbuhan Ekonomi

Hasil pengujian pengaruh PMA $\left(\mathrm{X}_{2}\right)$ terhadap pertumbuhan ekonomi $(\mathrm{Y})$ diperoleh nilai koefisien regresi sebesar 0.850813 dengan nilai signifikansi 0.3981 (di atas 0,05), artinya tidak terdapat pengaruh signifikan, dimana PMA secara individual tidak mempengaruhi Pertumbuhan Ekonomi.

Akan tetapi, jika dilihat dari perhitungan sebelumnya, yakni nilai koefisien dari masingmasing kabupaten penghasil batubara tersebut. Diperoleh bahwa setiap 1\% kenaikan PMA pada masing-masing kabupaten akan meningkatkan 0,02\% Pertumbuhan Ekonomi pada masing-masing kabupaten tersebut.

\section{KESIMPULAN DAN SARAN}

\section{Kesimpulan}

1. Secara simultan X1 (PAD), X2 (Dana Perimbangan) dan X3 (PMA) mempunyai pengaruh yang signifikan terhadap pertumbuhan ekonomi. Dan secara parsial, PAD dan PMA berpengaruh positif namun tidak signifikan terhadap pertumbuhan ekonomi pada 5 (lima) kabupaten penghasil batubara tersebut.

2. Hasil pengujian pengaruh PAD (X1) terhadap pertumbuhan ekonomi (Y) secara individual, diperoleh bahwa PAD tidak mempengaruhi Pertumbuhan Ekonomi, artinya tidak terdapat pengaruh signifikan. Akan tetapi, jika dilihat dari perhitungan sebelumnya, yakni nilai koefisien dari masing-masing kabupaten penghasil batubara tersebut. Diperoleh bahwa setiap 1\% kenaikan PAD pada masing-masing kabupaten akan meningkatkan 0,20\% Pertumbuhan Ekonomi pada masing-masing kabupaten tersebut.

3. Hasil pengujian pengaruh Dana Perimbangan $(\mathrm{X} 2)$ terhadap pertumbuhan ekonomi $(\mathrm{Y})$ secara individual, diperoleh bahwa Dana Perimbangan secara individual mempengaruhi Pertumbuhan Ekonomi, artinya terdapat pengaruh signifikan. Dan jika dilihat dari perhitungan sebelumnya, yakni nilai koefisien dari masing-masing kabupaten penghasil batubara tersebut. Diperoleh bahwa setiap 1\% kenaikan Dana Perimbangan pada masing-masing kabupaten akan meningkatkan 0,78\% Pertumbuhan Ekonomi pada masing-masing kabupaten tersebut.

4. Hasil pengujian pengaruh PMA (X2) terhadap pertumbuhan ekonomi (Y) secara individual, diperoleh bahwa PMA secara individual tidak mempengaruhi Pertumbuhan Ekonomi, artinya tidak terdapat pengaruh signifikan. Akan tetapi, jika dilihat dari perhitungan sebelumnya, yakni nilai koefisien dari masing-masing kabupaten penghasil batubara tersebut. Diperoleh bahwa setiap 1\% kenaikan PMA pada masing-masing kabupaten akan meningkatkan 0,02\% Pertumbuhan Ekonomi pada masing-masing kabupaten tersebut.

5. Kabupaten Muara Enim sebagai kabupaten yang memiliki jumlah rata-rata PDRB cukup tinggi (urutan nomor 2 setelah Kabupaten Musi Banyuasin) dan memiliki jumlah produksi batubara terbanyak serta memperoleh royalty dan land rent terbanyak, justru memiliki penduduk miskin terbesar kedua setelah Kabupaten Musi Banyuasin. 
6. Berbeda jauh dengan Kabupaten Musi Banyuasin yang memiliki jumlah rata-rata PDRB paling tinggi di antara 4 (empat) kabupaten lainnya, justru memiliki penduduk miskin paling banyak, meskipun jumlah produksi batubaranya menempati urutan nomor 2 setelah Kabupaten Muara Enim, termasuk royalty dan land rent yang diterima menempati urutan nomor 3 setelah Kabupaten Muara Enim dan Kabupaten Lahat.

\section{Saran}

1. Secara parsial, PAD dan PMA berpengaruh positif namun tidak signifikan terhadap pertumbuhan ekonomi pada 5 (lima) kabupaten penghasil batubara di Provinsi Sumatera Selatan, diharapkan masing-masing pemerintah daerah dapat mempertahankan dan meningkatkan infrastruktur untuk menarik investor asing sehingga dapat meningkatkan PAD.

2. Hasil produksi batubara, royalty dan land rent yang diterima belum mampu mengatasi jumlah penduduk miskin di daerah penghasil batubara, diharapkan masing-masing pemerintah daerah secara maksimal dapat mengalokasikan dana tersebut guna mengurangi jumlah penduduk miskin.

3. Untuk penelitian ke depan diharapkan untuk dapat menggunakan data yang lebih banyak lagi, baik variabel independennya maupun tahun data yang menjadi objek pangamatan hendaknya bisa lebih memuat jangka waktu yang lebih lama lagi.

\section{DAFTAR PUSTAKA}

Arsyad, Lincolin. 2002. Ekonomi Pembangunan : edisi kedua, STIE YKPN, Yogyakarta

Asngari, Imam. 2013. Econometrics, Program Pascasarjana Fakultas Ekonomi. Universitas Sriwijaya, Palembang.

Badan Pusat Statistik (BPS) Provinsi Sumatera Selatan. 2016, Pendapatan Domestik Regional Bruto (PMA) beberapa terbitan. Data Tahun 2002-2015.

D. Nachrowi, Nachrowi, dkk. 2006. Pendekatan Populer dan Praktis EKONOMETRIKA untuk Analisis Ekonomi dan Keuangan. Lembaga Penerbit Fakultas Ekonomi Universitas Indonesia : Jakarta.

Dinas Pendapatan Asli Daerah (DISPENDA) Provinsi Sumatera Selatan. 2016, Data Tahun 2002-2015.

Dinas Pertambangan dan Energi (DISTAMBEN) Provinsi Sumatera Selatan. 2016, Data Tahun 20022015.

Fujiansyah, Deki. 2016. Pengaruh Belanja Pemerintah, Dana Perimbangan dan Investasi Swasta Terhadap Disparitas Regional Kabupaten/Kota di Provinsi Sumatera Selatan Tahun 2010-2014. Universitas Sriwijaya, Palembang.

Iqbal, Hasan. 2002. Metode Penelitian dan Aplikasinya. Cetakan Pertama.Jakarta.

Prakarsa, Febrian Dwi. 2014. Analisis Pengaruh Pendapatan Asli Daerah dan Pengeluaran Pemerintah Daerah Terhadap Pertumbuhan Ekonomi (Studi Kasus di Kabupaten Kota Jawa Timur Tahun 2008-2012), Jurnal Universitas Brawijaya, Malang.

R. Ajija, Shochrul, dkk. 2011. Cara Cerdas Menguasai Eviews. Penerbit Salemba Empat: Jakarta.

Richard, A. Musgrave. 1959. The Theory of Public Finance. McGraw-Hill Mogakusha, Ltd. Tokyo : Japan..

Rizky, Reza Lainatul, dkk. 2016. Pengaruh Penanaman Modal Asing, Penanaman Modal Dalam Negeri dan Belanja Modal Terhadap Pertumbuhan Ekonomi Provinsi di Indonesia. Jurnal Universitas Negeri Malang.

Sjafrizal. 2008. Ekonomi Regional Teori dan Aplikasi. Baduose Media. Padang Sumatera Barat Subianto, 2015. Analisis Pengaruh Investasi, Pengeluaran Pemerintah dan Pendapatan Daerah Terhadap Pertumbuhan Ekonomi Kabupaten Musi Rawas. Tesis Universitas Sriwijaya.

Sukirno, Sadono. 1985. Pengantar Teori Mikroekonomi. Lembaga Penerbit FEUI. Jakarta Sumarwan.

Suparmoko. 2001. Ekonomi Publik (Untuk Keuangan dan Pembangunan Daerah). Edisi Pertama. Penerbit Andi : Yogyakarta. 
Suryana, 2000. Ekonomi Pembangunan: Problematika dan Pendekatan. Edisi Pertama, Jakarta: Salemba Empat.

Todaro, M.P. 2000. Economic Development, Seventh Edition, New York, Addition Wesley Longman, Inc

Todaro.M. dan Smith. 2004. Pembangunan Ekonomi di Dunia Ketiga. Pearson Education Limited. United Kingdom

Todaro M.P. 2006. Pembangunan Ekonomi di Dunia Ketiga, Penerbit Erlangga, Jakarta.

Ulbrich, Holley. 2003. Public Finance : in Theory and Practice. Thomson : South Western, USA..

Undang-Undang Nomor 23 Tahun 2014 tentang Pemerintahan Daerah

http://www.djpk.depkeu.go.id/

http://www.sjdih.depkeu.go.id

http://natanellainsamputty.blogspot.co.id/2015/07/perimbangan-keuangan-antara-pusat-dan.html

http://abstraksiekonomi.blogspot.co.id/2014/10/teori-pertumbuhan-ekonomi-daerah.html

http://nur-qomariyah-fisip14.web.unair.ac.id/artikel_detail-161799-

POLITIK\%20KEUANGAN\%20DAN\%20ANGGARAN-

ANALISIS\%20POLITIK\%20KEUANGAN\%20DAN\%20ANGGARAN\%20DALAM\%20PENYUSUNAN\%

20KUA/PPAS\%20PADA\%20APBD\%20KABUPATEN\%20BANYUWANGI\%202015.html

https://www.scribd.com/doc/179343552/Karya-Tulis-Ilmiah

http://www.databoks.com

518 | Muhammad Ikbal Aziz, Bernadette Robiani, Azwardi; The Analysis of Local Revenues ... 